\title{
UPAYA MENINGKATAN KEMAMPUAN BERPIKIR KRITIS SISWA MENGGUNAKAN MODEL PEMBELAJARAN IMPROVE
}

\author{
Oleh: \\ Tety Septiani \\ Program Studi Pendidikan Matematika, Universitas Muhammadiyah Purwokerto \\ tetyseptiani@gmail.com
}

\begin{abstract}
:
This research aims to improve students' critical thinking skill using IMPROVE learning model. The subject of this research were VII D grade students of SMP Negeri 9 Purwokerto in the academic year of 2016/2017, consisted of 18 male students and 18 female students. This research employed classroom action research with 3 cycles consisted of planning, acting, observing, and reflecting. In order to know students' critical thinking skill, the researcher used intrument of essay test given in the end of each cycle. The results indicate that students' critical thinking skill improves in cycle I with the mean score is 53.56; then it improves in cycle II with the mean score is 67.87; and it improves in cycle II with the mean score is 77.44. It can be concluded that IMPROVE learning model can improve students' critical thinking skill at VII D grade students of SMP Negeri 9 Purwokerto.
\end{abstract}

Keyword: Critical Thinking Skill, IMPROVE Learning Model

\section{PENDAHULUAN}

Standar Kompetensi Lulusan (SKL) mata pelajaran matematika di SMP/MTs salah satunya ialah siswa harus memiliki kemampuan berpikir logis, analitis, sistematis, kritis, dan kreatif, serta mempunyai kemampuan untuk bekerja sama (Permendiknas Nomor 23 Tahun 2006).Kurikulum dan evaluasi disusun sebagai suatu standar dalam usaha memberi kesempatan kepada siswa dalam berbagai tingkat satuan pendidikan untuk mengansumsi informasi secara kritis (NCTM, 1989). Ini berarti kemampuan berpikir kritis merupakan salah satu komponen yang penting dalam matematika.

Berpikir kritis adalah suatu pemikiran reflektif dan proses sistematis yang dilakukan untuk merumuskan, memutuskan, dan mengevaluasi suatu keyakinan (Ennis:1985, Johnson:2002). Berpikir kritis merupakan pertimbangan yang aktif, persistent (terus menerus) dan teliti mengenai sebuah keyakinan atau bentuk pengetahuan yang diterima begitu saja dipandang dari sudut alasan-alasan yang mendukungnya dan kesimpulan-kesimpulan lanjutan yang menjadi kecenderungannya (Dewey dalam Fisher, 2007). Berdasarkan beberapa definisi yang telah dikemukakan, dapat disimpulkan bahwa berpikir kritis adalah kemampuan untuk berpikir secara logis dan reflektif yang diaplikasikan dalam menguji keyakinan sebuah informasi atau pengetahuan berdasarkan bukti pendukung dan kesimpulan-kesimpulan 
Journal of Mathematics Education, 4(1) Mei 2018 lanjutan yang diakibatkannya. Maksudnya, siswa dituntut bukan hanya untuk memindahkan rumus ke dalam penyelesaian, tetapi mengerti apa yang ditanyakan, konsep dan strategi apa yang digunakan dalam menentukan solusi dari permasalahan matematika serta menyimpulkannya. Oleh karena itu, mengajarkan dan mengembangkan kemampuan berpikir kritis dipandang sebagai sesuatu yang penting untuk dikembangkan di sekolah agar siswa mampu dan terbiasa menghadapi permasalahan disekitarnya.

Ada beberapa kemampuan dalam berpikir kritis, yaitu: (1) mengenal masalah; (2) menemukan cara-cara yang dapat dipakai untuk menangani masalah-masalah itu; (3) mengumpulkan dan menyusun informasi yang diperlukan; (4) mengenal asumsi-asumsi dan nilai-nilai yang tidak dinyatakan; (5) memahami dan menggunakan bahasa yang tepat, jelas, dan khas; (6) menganalisis data; (7) menilai fakta dan mengevaluasi pernyataan-pernyataan; (8) mengenal adanya hubungan yang logis antara masalah-masalah; (9) menarik kesimpulan-kesimpulan dan kesamaan-kesamaan yang diperlukan; (10) menguji kesamaan-kesamaan dan kesimpulankesimpulan yang seseorang ambil; (11) menyusun kembali pola-pola keyakinan seseorang berdasarkan penglaman yang lebih luas; dan (12) membuat penilaian yang tepat tentang halhal dan kualitas-kualitas tertentu dalam kehidupan sehari-hari (Glaser dalam Fisher, 2007). Indikator kemampuan berpikir kritis ada 1, yaitu: (1) memfokuskan pertanyaan; (2) menganalisis argumen; (3) bertanya dan menjawab pertanyaan tentang suatu penjelasan atau tantangan; (4) mempertimbangkan kredibilitas suatu sumber; (5) mengobservasi dan mempertimbangkan hasil observasi; (6) membuat deduksi dan mempertimbangkan hasil deduksi; (7) membuat induksi dan mempertimbangkan hasil induksi; (8) membuat keputusan dan mempertimbangkan hasilnya; (9) mendefinisikan istilah dan mempertimbangkan definisi; (10) mengidentifikasi asumsi; (11) memutuskan suatu tindakan; dan (12) berinteraksi dengan orang lain (Ennis:1985, Angelo:1995).

Berdasarkan indikator-indikator kemampuan berpikir kritis menurut para ahli di atas, maka indikator kemampuan berpikir kritis yang akan digunakan peneliti adalah sebagai berikut:

\section{Kemampuan Menganalisis}

Kemampuan menganalisis merupakan suatu kemampuan memilah atau menjabarkan sesuatu kedalam unsur-unsur atau bagian-bagian sehingga jelas susunannya atau tampak jelas hubungan antara berbagai gagasan yang dinyatakan (Sudjana:2010, Suryosubroto:2009). Ada beberapa kata-kata kunci pertanyaan analisis yaitu analisislah, 
Upaya Meningkatan Kemampuan Berpikir Kritis Siswa Menggunakan Model Pembelajaran Improve

kemukakan bukti-bukti, mengapa, identifikaskan, tunjukkan sebabnya, dan berilah alasan-alasan (Kemendikbud, 2014).

2. Kemampuan Mensitesis

Kemampuan mensintesis merupakan kemampuan menggabungkan unsur-unsur atau bagian-bagian sedemikian rupa sehingga membentuk suatu keseluruhan yang utuh (Sudjana:2010, Suryosubroto:2009). Ada beberapa kata-kata kunci pertanyaan sintesis yaitu ramalkanlah, susunlah, tulislah, kembangkan, dll (Kemendikbud, 2014).

3. Kemampuan Mengenal dan Memecahkan Masalah

Kemampuan memecahkan masalah merupakan kemampuan untuk mencari jalan keluar dari suatu kesulitan guna mencapai suatu tujuan (Polya, 1985). Kemampuan ini menuntut siswa untuk memahami bacaan sehingga setelah kegiatan membaca selesai siswa mampu menangkap beberapa pikiran pokok bacaan. Kemampuan ini bertujuan agar siswa mampu memahami dan menerapkan konsep-konsep ke dalam permasalahan atau ruang lingkup baru.

4. Kemampuan Menyimpulkan

Kemampuan menyimpulkan merupakan kemampuan seseorang untuk mengidentifikasi dan mengamankan informasi yang diperlukan untuk menggambarkan kesimpulan (Afrizon, 2012). Kemampuan ini menuntut untuk mampu menguraikan dan memahami berbagai aspek secara bertahap untuk menghasilkan sebuah pemikiran atau pengetahuan yang baru.

5. Kemampuan Mengevaluasi atau Menilai

Kemampuan mengevaluasi merupakan kemampuan untuk menetapkan nilai atau harga dari suatu bahan atau metode komunikasi untuk tujuan-tujuan tertentu (Suryosubroto, 2009). Ada beberapa kata-kata kunci pertanyaan evaluasi yaitu berilah pendapat, berilah alasan, nilailah, bedakanlah, setujukah anda, bandingkan, dll (Kemendikbud, 2014).

Berdasarkan hasil wawancara terhadap guru matematika diketahui bahwa nilai rata-rata Ulangan Akhir Semester (UAS) mata pelajaran matematika semester gasal tahun pelajaran 2016/2017 di SMP N 9 Purwokerto, kelas VII D merupakan kelas yang memperoleh nilai rata-rata terkecil dibandingkan dengan kelas lainnya, sehingga yang dijadikan subjek penelitian adalah kelas VII D. Menurut guru mata pelajaran matematika di kelas VII D, ada beberapa hal yang menjadi penyebabnya, yaitu: 1) tingkat penguasaan materi siswa yang masih rendah; 2) siswa belum bisa menyatukan informasi yang diperoleh dari bacaannya; 3) siswa belum mampu menguraikan atau mengidentifikasi permasalahan yang dijumpainya; 4) siswa masih merasa kesulitan menerapkan konsep-konsep kedalam suatu permasalahan; 5) 
Journal of Mathematics Education, 4(1) Mei 2018 siswa masih kesulitan dalam memberikan penilaian terhadap benar salahnya suatu argumen; 6) siswa masih merasa kesulitan dalam menyimpulkan. Hal ini menunjukkan bahwa kemampuan berpikir kritis siswa masih rendah.

Kurangnya kemampuan berpikir kritis siswa juga diperkuat dengan hasil tes kemampuan awal siswa kelas VII D. Tes kemampuan awal ini dilakukan untuk mengetahui tingkat kemampuan berpikir kritis siswa pada setiap indikator, dengan hasil skor rata-rata indikator kemampuan menganalisis sebesar 2,03; indikator kemampuan mensintesis sebesar 1,25; indikator kemampuan mengenal dan memecahkan masalah sebesar 1,42; indikator kemampuan menyimpulkan sebesar 2,08; dan indikator kemampuan mengevaluasi atau menilai sebesar 1,28. Secara keseluruhan diperoleh skor rata-rata kemampuan berpikir kritis sebesar 1,61 dengan kriteria cukup.

Selain disebabkan oleh faktor siswa itu sendiri, faktor lainnya yang dapat berakibat pada kemampuan berpikir kritis siswa adalah penggunaan model pembelajaran yang kurang tepat. Proses pembelajaran metematika yang berlangsung di sekolah saat ini masih banyak didominasi oleh guru, dimana guru sebagai sumber utama pengetahuan sehingga guru memegang peranan penting dalam pelaksanaan pembelajaran. Model pembelajaran yang umum dilakukan oleh guru yaitu model pembelajaran lansung dengan metode ceramah. Pada metode ini kadang-kadang konsentrasi siswa terpecah dengan hal lain, akibatnya siswa kurang memahami materi pelajaran. Demikian juga dengan mata pelajaran matematika yang bersifat abstrak. Guru dapat membuat siswa merasa tertarik dan termotivasi dengan berbagai cara, misalnya dengan menggunakan pendekatan dan media pembelajaran yang sesuai dengan materi yang akan diajarkan agar siswa dapat berfikir secara kritis, logis, dan dapat memecahkan masalah dengan sikap terbuka, kreatif dan inovatif serta tidak membosankan. Membawa ke arah pembelajaran yang dapat mengembangkan kemampuan berpikir kritis harus berangkat dari pembelajaran yang membuat siswa aktif (Ibrahim dalam Istianah, 2013).

Salah satu model pembelajaran yang memfasilitasi siswa untuk meningkatkan kemampuan berpikir kritis adalah model pembelajaran IMPROVE. Model pembelajaran IMPROVE merupakan model yang didesain pertama kali oleh Mevarech dan Kramarski (1997). IMPROVE merupakan sebuah akronim dari Introducing New Concepts, Metacognitive questioning, Practicing, Reviewing and reducing difficulties, Obtaining mastery, Verification, dan Enrichment. 


\section{Tety Septiani}

Upaya Meningkatan Kemampuan Berpikir Kritis Siswa Menggunakan Model Pembelajaran Improve

Berikut ini merupakan penjabaran sintak model pembelajaran IMPROVE:

1. Introducing New Concepts (mengantarkan konsep baru)

Pada tahap ini guru berperan fasilitator untuk membimbing siswa menemukan konsep secara mandiri, hal ini dicirikan dengan guru tidak memberikan begitu saja hasil akhir dari suatu konsep. Guru membimbing siswa menemukan suatu konsep dengan memberikan pertanyaanpertanyaan yang mengarah pada penemuan suatu konsep, dengan ini diharapkan pemahaman siswa terhadap suatu konsep dapat bertahan lama karena siswa turut aktif menemukan dan memahami konsep baru.

2. Metacognitive questioning (mengajukan pertanyaan metakognitif)

Pertanyaan metakognitif meliputi, sebagai berikut:

a. Pertanyaan pemahaman mendorong siswa membaca soal, menggambarkan suatu konsep dengan kata-kata sendiri, dan mencoba memahami makna suatu konsep. Adapun contoh dari pertanyaan pemahaman, yaitu: "Berikan contoh benda yang permukaannya berbentuk persegi panjang?"

b. Pertanyaan koneksi mendorong siswa untuk melihat persamaan dan perbedaan suatu konsep/permasalahan. Adapun contoh dari pertanyaan koneksi, yaitu: "Bagaimana cara menentukan rumus keliling dan luas belah ketupat? Apakah cara menentukan rumus keliling dan luas belah ketupat sama dengan rumus keliling dan luas persegi?"

c. Pertanyaan strategi mendorong siswa untuk mempertimbangkan strategi yang cocok dalam menyelesaikan masalah yang diberikan serta menyertakan alasan pemilihan strategi tersebut. Adapun contoh dari pertanyaan strategi, yaitu: "Untuk menentukan keliling trapesium, apakah strategi menjumlahkan semua sisi-sisinya merupakan strategi/cara yang tepat? Lalu bagaimana dengan strategi/cara menentukan luas trapesium?"

d. Pertanyaan refleksi merupakan pertanyaan yang mendorong siswa untuk bertanya pada diri sendiri mengenai proses penyelesaian. Adapun contoh dari pertanyaan refleksi, meliputi: "Kesulitan apa yang dihadapi dalam memecahkan masalah untuk menentukan luas layang-layang?’(Kramarski et al., 2002)

3. Practicing (Latihan)

Pada tahap ini guru memberikan latihan kepada siswa secara kelompok dalam bentuk soalsoal. Siswa berlatih memecahkan masalah yang diberikan oleh guru. Hal ini sangat bermanfaat untuk meningkatkan penguasaan materi dan mengasah kemampuan siswa.

4. Reviewing and reducing difficulties (Mengulas dan mereduksi kesulitan) 
Journal of Mathematics Education, 4(1) Mei 2018 Pada tahap ini guru melakukan pengulasan atau pembahasan terhadap kesulitan-kesulitan yang dialami siswa sewaktu memahami materi atau menjawab soal-soal, guru dapat melakukan ini dengan diskusi kelas, selanjutnya guru memberikan solusi guna menjawab kesulitan-kesulitan yang dialami siswa.

5. Obtaining mastery (Penguasaan materi)

Pada tahap ini guru akan mengetahui tingkat penguasaan materi siswa secara individu atau keseluruhan, hal ini dapat dilakukan dengan memberikan tes kepada siswa sesuai materi yang telah dipelajari.

6. Verification (Verifikasi)

Pada tahap ini guru mengidentifikasi siswa yang telah memahami atau menguasai materi dan siswa yang belum menguasai materi dengan melihat hasil tes yang telah diberikan pada tahap sebelumnya.

7. Enrichment (Pengayaan)

Pada tahap ini guru memberikan respon terhadap hasil verifikasi, siswa yang belum menguasai materi diberikan pengulangan/perbaikan.

Hal yang membedakan model pembelajaran IMPROVE dengan model pembelajaran lain adalah dalam pembelajaran dengan model pembelajaran IMPROVE, siswa diberi pertanyaanpertanyaan metakognitif dengan belajar berkelompok. Siswa juga disituasikan untuk belajar berkelompok dalam menyelesaikan masalah-masalah yang ada. Kelompok tersebut terdiri dari siswa yang heterogen. Situasi belajar berkelompok yang heterogen ini dapat menonjolkan interaksi dalam kelompok seperti tanya jawab, tukar pendapat, dan debat antar siswa. Selain dari itu, belajar berkelompok mampu membuat siswa menerima siswa lain yang berkemampuan latar belakang yang berbeda.

Berdasarkan uraian di atas, peneliti melakukan penelitian yang berjudul "Upaya Meningkatkan Kemampuan Berpikir Kritis Siswa Menggunakan Model Pembelajaran IMPROVE pada Kelas VII D SMP Negeri 9 Purwokerto".

\section{METODE PENELITIAN}

Penelitian ini telah dilaksanakan di kelas VII D SMP Negeri 9 Purwokerto pada semester genap tahun pelajaran 2016/2017 dari tanggal 7 April 2017 - 23 Mei 2017. Jenis penelitian yang digunakan adalah Penelitian Tindakan Kelas (PTK) yang terdiri dari 3 siklus dengan setiap siklus diadakan 3 kali pertemuan. Subyek penelitian ini adalah siswa kelas VII D SMP 
Negeri 9 Purwokerto tahun pelajaran 2016/2017 yang berjumlah 36 siswa yang terdiri dari 18 siswa laki-laki dan 18 siswa perempuan.

Prosedur penelitian tindakan kelas ini meliputi 4 tahapan penting, yaitu perencanaan, pelaksanaan tindakan, observasi, dan refleksi (Arikunto, dkk., 2008). Teknik pengumpulan data yang digunakan dalam penelitian ini adalah observasi, tes kemampuan berpikir kritis, dan dokumentasi. Teknik analisis data yang digunakan dalam penelitian ini adalah dengan menganalisis hasil observasi aktivitas guru dan hasil observasi aktivitas siswa secara deskriptif serta menghitung nilai tes evaluasi kemamouan berpikir kritis. Setiap akhir siklus diadakan evaluasi menggunakan tes untuk mengukur kemampuan berpikir kritis siswa. Setelah diperoleh hasil akhir tes pada tiap siklus kemudian dianalisis berdasarkan pedoman penskoran yang telah dirancang.

Penelitian ini dikatakan berhasil apabila terdapat peningkatan nilai rata-rata kemampuan berpikir kritis siswa dari siklus I sampai siklus III dengan nilai rata-rata kemampuan berpikir kritis siswa telah mencapai $\geq 72$.

\section{HASIL DAN PEMBAHASAN}

Berdasarkan hasil penelitian pada pelaksanaan siklus I sampai dengan siklus III pada kelas VII D SMP Negeri 9 Purwokerto melalui model pembembelajaran IMPROVE yang dilaksanakan pada tanggal 7 April 2017 - 23 Mei 2017 dapat diuraikan sebagai berikut:

\section{Aktivitas Guru}

Hasil observasi aktivitas guru selama proses pembelajaran dari siklus I sampai siklus III semakin baik dan sesuai dengan prosedurnya. Hal ini ditunjukkan ketika guru melaksanakan kegiatan-kegiatan disetiap tahap pembelajaran IMPROVE. Pada siklus I pertemuan kedua guru tidak menyampaikan tujuan pembelajaran dan apersepsi sedangkan pada siklus II pertemuan kedua guru tidak menyampaikan apersepsi terkait materi yang akan diajarkan. Pada siklus III pertemuan pertama dan kedua, guru sudah menyampaikan tujuan pembelajaran sehingga siswa mengetahui apa yang hendak dicapai pada setiap pembelajaran dan guru sudah menyampaikan apersepsi.

Pada saat pelaksanaan tahap Practicing pada siklus I, guru belum menjelaskan langkahlangkah pengerjaan LKS, sehingga siswa bingung dalam mengerjakan LKS. Namun, pada siklus berikutnya guru sudah menjelaskan langkah-langkah pengerjaan LKS, sehingga hal tersebut memudahkan siswa saat mengerjakan LKS. Pada siklus I pertemuan pertama, yaitu 
Journal of Mathematics Education, 4(1) Mei 2018 pada tahap Reviewing and Reducing Difficulties, guru tidak membimbing siswa untuk menyajikan hasil diskusi kelompok akan tetapi pada pertemuan selanjutnya guru selalu membimbing siswa saat menyajikan hasil diskusi kelompok.

Guru tidak melaksanakan tahap Obtaining Mastery pada siklus I pertemuan pertama dan guru juga tidak melaksanakan tahap Verification, khususnya pada kegiatan mengevaluasi jawaban siswa pada siklus I pertemuan pertama dan kedua. Tidak terlaksananya tahap Obtaining Mastery dan Verification tersebut dikarenakan guru belum bisa mengatur waktu untuk pembelajaran dengan baik. Namun, pada siklus berikutnya tahap Obtaining Mastery dan Verification dapat terlaksana dengan baik, karena guru sudah berusaha untuk bisa mengatur waktu dalam pembelajaran sesuai dengan RPP.

Pada siklus I pertemuan pertama, guru tidak memberikan perbaikan terhadap hasil jawaban soal kuis siswa dikarenakan tidak terlaksananya tahap Obtaining Mastery dan Verification. Akan tetapi, pada siklus berikutnya guru berupaya untuk meminimalisir kekurangan dalam melaksanakan aktivitas permbelajaran siklus sebelumnya. Hal ini ditunjukkan dengan terlaksananya semua kegiatan pembelajaran sesuai dengan RPP. Pemahaman guru yang semakin meningkat terhadap tahapan pembelajaran IMPROVE dan upaya guru untuk memperbaiki kekurangan dalam melaksanakan aktivitas pembelajaran pada setiap siklusnya membuat pembelajaran dapat berjalan sesuai dengan prosedurnya.

\section{Aktivitas Siswa}

Pada siklus I masih banyak siswa yang tidak memperhatikan saat guru menyampaikan tujuan pembelajaran, apersepsi dan motivasi. Namun, pada siklus selanjutnya siswa sudah memperhatikan saat guru menyampaikan tujuan pembelajaran, apersepsi, dan motivasi karena guru menasehati siswa yang tidak memperhatikan. Pada siklus I, masih banyak siswa yang bingung saat guru memberi arahan untuk menemukan konsep suatu rumus menghitung keliling dan luas bangun datar segiempat. Hal tersebut dikarenakan biasanya siswa langsung diberikan rumus yang sudah ada tanpa mengetahui asal rumus tersebut. Pada siklus II dan siklus III, siswa sudah bisa mengikuti arahan guru untuk menemukan konsep suatu rumus menghitung keliling dan luas bangun datar segiempat, sehingga dengan cara ini pemahaman siswa terhadap suatu konsep akan bertahan lama karena siswa turut aktif menemukan suatu konsep.

Pada tahap Metacognitive Questioning siklus I, siswa masih kesulitan mengikuti arahan guru untuk menyelesaikan suatu permasalahan otentik yang berkaitan dengan materi. Namun, pada 


\section{Tety Septiani}

Upaya Meningkatan Kemampuan Berpikir Kritis Siswa Menggunakan Model Pembelajaran Improve

siklus selanjutnya siswa secara bertahap bisa mengikuti arahan guru untuk menyelesaikan suatu permasalahan otentik sehingga siswa dapat mempertimbangkan strategi yang tepat untuk menyelesaikan suatu masalah, menyelesaikan suatu masalah yang diberikan guru, dan mengetahui kesulitan saat melakukan proses penyelesaian masalah tersebut.

Pada tahap Practicing siklus I, siswa masih pasif dalam mendiskusikan permasalahan yang ada di LKS. Siswa belum bisa mengumpulkan berbagai informasi untuk menyelesaikan permasalahan pada LKS, mempertimbangkan strategi yang tepat untuk menyelesaikan permasalahan pada LKS, dan mengetahui kesulitan saat melakukan proses penyelesaian masalah pada LKS. Siswa juga masih tidak berani untuk menyajikan hasil diskusi kelompoknya ke depan kelas, hal tersebut terlihat saat siswa harus ditunjuk dahulu oleh guru untuk menyajikan hasil diskusinya. Hal tersebut tidak terjadi lagi pada siklus berikutnya karena siswa sudah mulai aktif dalam berkelompok, terlihat pada saat proses diskusi berlangsung banyak siswa yang aktif untuk bertanya mengenai kesuliatannya dalam mengerjakan LKS. Siswa juga sudah mampu mengumpulkan berbagai informasi dari sumber belajar yang ada untuk menyelesaikan permasalahan pada LKS, mempertimbangkan strategi yang tepat untuk menyelesaikan permasalahan pada LKS, mengetahui kesulitan saat melakukan proses penyelesaian masalah pada LKS, dan siswa sudah berani mengajukan diri untuk menyajikan hasil diskusi kelompoknya ke depan kelas.

Pada siklus I pertemuan pertama, siswa harus mengerjakan soal kuis di rumah masingmasing. Namun, pada pertemuan selanjutnya siswa bisa mengerjakan soal kuis di kelas secara individu dan siswa bisa menerima hasil evaluasi dari jawabannya. Jumlah siswa yang mendapat nilai tuntas (nilai > 70) untuk hasil evaluasi soal kuis selalu meningkat dari siklus I sampai siklus III, begitupun juga dengan nilai rata-ratanya. Hal tersebut dapat ditunjukkan dari tabel berikut:

Tabel 1. Rekapitulasi Nilai Kuis

\begin{tabular}{lcccccc}
\hline & \multicolumn{2}{c}{ Siklus I } & \multicolumn{2}{c}{ Siklus II } & \multicolumn{2}{c}{ Siklus III } \\
\cline { 2 - 7 } & P 1 & P 2 & P 1 & P 2 & P 1 & P 2 \\
\hline Nilai rata-rata & 64,17 & 70,28 & 73,61 & 76,94 & 82,22 & 90,56 \\
$\begin{array}{l}\text { Jumlah siswa } \\
\text { (nilai }>\text { 70) }\end{array}$ & 11 & 19 & 23 & 25 & 29 & 33 \\
\hline
\end{tabular}

Keterangan :

$\mathrm{P} 1$ = pertemuan pertama, $\mathrm{P} 2$ = pertemuan kedua

Pada kegiatan penutup siklus I, siswa masih belum ikut menyimpulkan materi yang telah. Akan tetapi pada siklus selanjutnya, siswa bersama dengan guru menyimpukan materi yang telah dipelari dan siswa juga menyimak saat guru menyampaikan agar siswa mempelajari 
Journal of Mathematics Education, 4(1) Mei 2018 materi untuk pertemuan berikutnya di rumah. Berdasarkan hasil observasi aktivitas siswa selama pembelajaran IMPROVE, secara keseluruhan mengalami peningkatan dari setiap siklusnya, sehingga dapat memotivasi siswa untuk aktif dalam mengikuti pembelajaran.

\section{Tes Evaluasi Kemampuan Berpikir Kritis}

Peneliti memberikan tes evaluasi kemampuan berpikiri kritis pada setiap akhir siklus I hingga siklus III untuk mengetahui kemampuan berpikir kritis siswa. Adapun hasil tes kemampuan berpikir kritis siswa yang telah diadakan pada akhir siklus I hingga siklus III adalah sebagai berikut:

Tabel 2. Skor Tes Tiap Indikator Kemampuan Berpikir Kritis Siswa

\begin{tabular}{clccc}
\hline \multirow{2}{*}{ No. } & \multicolumn{1}{c}{ Indikator } & \multicolumn{3}{c}{ Siklus ke } \\
\cline { 3 - 5 } & & I & II & III \\
\hline 1. & Kemampuan menganalisis & 3,31 & 3,94 & 4,31 \\
2. & Kemampuan mensintesis & 2,24 & 3,58 & 3,82 \\
3. & Kemampuan mengenal dan memecahkan & 2,07 & 2,56 & 3,47 \\
4. & Kemasalah & 3,75 & 3,78 & 4,08 \\
5. & Kemampuan menyimpulkan & 2,03 & 3,10 & 3,68 \\
\hline \multicolumn{2}{r}{ Rata-rata tiap siklus } & $\mathbf{2 , 6 8}$ & $\mathbf{3 , 3 9}$ & $\mathbf{3 , 8 7}$ \\
\hline
\end{tabular}

Adapun nilai tes evaluasi kemampuan berpikir kritis siswa dari siklus I hingga siklus III adalah sebagai berikut:

Tabel 3. Nilai Tes Evaluasi Kemampuan Berpikir Kritis

\begin{tabular}{cccc}
\hline Pencapaian & Siklus I & Siklus II & Siklus III \\
\hline Nilai Terendah & 18,00 & 25,33 & 32,00 \\
Nilai Tertinggi & 66,00 & 92,00 & 92,00 \\
Nilai Rata-rata & 53,56 & 67,87 & 77,44 \\
\hline
\end{tabular}

Berdasarkan tabel 3 di atas, terlihat bahwa nilai rata-rata tes evaluasi kemampuan berpikir kritis siswa mengalami peningkatan dari siklus I ke siklus II dan ke siklus III. Adanya peningkatan nilai rata-rata tes evaluasi kemampuan berpikir kritis siswa dari siklus hingga siklus III dipengaruhi oleh aktivitas guru dan aktivitas siswa selama pembelajaran berlangsung. Guru telah melaksanakan kegiatan pembelajaran sesuai dengan Rencana Pelaksanaan Pembelajaran (RPP). Kegiatan yang dimaksud adalah kegiatan pembelajaran menggunakan model pembelajaran IMPROVE diantaranya kegiatan pendahuluan, kegiatan inti yang meliputi tahap Introducing New Concepts, Metacognitive Questioning, Practicing, Reviewing and Reducing Difficulties, Obtaining Mastery, dan Verification, serta kegiatan penutup yang mencakup tahap Enrichment. 


\section{Tety Septiani}

Upaya Meningkatan Kemampuan Berpikir Kritis Siswa Menggunakan Model Pembelajaran Improve

Kegiatan pada pembelajaran IMPROVE telah dilaksanakan oleh guru dan mengalami peningkatan pada setiap siklusnya. Hal tersebut membuat guru dan siswa semakin terbiasa dan terampil dalam mengikuti kegiatan-kegiatan yang ada selama pembelajaran berlangsung. Selain itu, siswa juga sudah terbiasa untuk menemukan suatu konsep dari bimbingan guru yang mengarah pada penemuan suatu konsep, sehingga dengan cara ini pemahaman siswa terhadap suatu konsep akan bertahan lama karena siswa turut aktif menemukan suatu konsep.

Pemberian latihan berupa LKS yang dikerjakan secara berkelompok juga bermanfaat untuk meningkatkan penguasaan materi dan mengasah kemampuan siswa, di dalam kelompok siswa terlibat aktif untuk menyelesaikan permasalahan yang terdapat pada LKS. Selain LKS, siswa juga diberikan tes pada setiap pembelajaran untuk mengetahui tingkat penguasaan materi siswa secara individu atau keseluruhan yang hasil dari jawaban tes tersebut langsung di evaluasi oleh guru, sehingga guru bisa mengetahui siswa yang belum menguasai materi maupun sebaliknya. Siswa yang belum tuntas dalam mengerjakan tes kemudian diberi perbaikan oleh guru untuk mengerjakan kembali soal tes yang telah dikerjakan.

Adanya pemberian permasalahan otentik, latihan berupa LKS dan tes pada setiap pembelajaran serta perbaikan bagi siswa yang belum tuntas mengerjakan tes ini bermanfaat bagi siswa untuk meningkatkan kemampuan berpikir kritisnya, sehingga hasil yang diperoleh siswa dalam tes evaluasi kemampuan berpikir kritis mengalami peningkatan dari siklus I ke siklus II, yaitu dari nilai rata-rata siklus I sebesar 53,56 meningkat pada siklus II menjadi 67,87. Begitu pula dari siklus II ke siklus III, yaitu dari nilai rata-rata siklus II sebesar 67,87 meningkat pada siklus III menjadi 77,44. Hal ini menunjukkan bahwa kemampuan berpikir kritis siswa sudah memenuhi indikator keberhasilan, yaitu nilai rata-rata $\geq 72$. Berdasarkan hal tersebut maka dapat disimpulkan bahwa model pembelajaran IMPROVE dapat meningkatkan kemampuan berpikir kritis siswa kelas VII D SMP Negeri 9 Purwokerto pada semester genap tahun pelajaran 2016/2017.

\section{KESIMPULAN}

Berdasarkan hasil penelitian dan pembahasan dapat disimpulkan bahwa pembelajaran matematika menggunakan model pembelajaran IMPROVE dapat meningkatkan kemampuan berpikir kritis siswa kelas VII D SMP Negeri 9 Purwokerto, khususnya pada materi segiempat. Hal ini dapat dilihat dari adanya peningkatan pada hasil tes evaluasi kemampuan berpikir kritis siswa dari siklus I sampai siklus III. Pada siklus I diperoleh nilai rata-rata kemampuan berpikir kritis siswa sebesar 53,56; pada siklus II diperoleh nilai rata-rata 
Journal of Mathematics Education, 4(1) Mei 2018 kemampuan berpikir kritis siswa sebesar 67,87; dan pada siklus III diperoleh nilai rata-rata kemampuan berpikir kritis siswa sebesar 77,44.

\section{DAFTAR PUSTAKA}

Afrizon, R, dkk. (2012). "Peningkatan Perilaku Berkarakter dan Keterampilan Berpikir Kritis Siswa Kelas IX MTsN Model Padang Pada Mata Pelajaran IPA-Fisika Menggunakan Model Problem Based Instruction". Jurnal Penelitian Pembelajaran Fisika, Vol 1, 1-16. [Online]. Tersedia di : http://ejournal.unp.ac.id/index.php/jppf/article/ viewFile/598/517 [20 November 2016]

Angelo, T. A. (1995). "Beginning the Dialogue: Thoughts on Promoting Critical Thinking". Teaching of Psycology, Vol 22(1), 6-7. [Online]. Tersedia di: http://www.chaffey.edu/slo/cm_slo_toolbox/Core\%20Competency\%20\%20Critical\%20Think ing/Beginning\%20the\%20Dialogue\%20Thoughts\%20on\%20Promoting\%20

Critical\%20Thinking.pdf [17 Desember 2016]

Arikunto, S. dkk. (2008). Penelitian Tindakan Kelas. Jakarta : Bumi Aksara

Depdiknas. (2006). Permendiknas Nomor 23 Tahun 2006 Tentang Standar Kompetensi Lulusan. Jakarta : Depdiknas

Ennis, R. H. (1985). “A Logical Basis for Measuring Critical Thinking Skills”. Educational Leadership, Vol 43(2), 44-48. [Online]. Tersedia di : http://www.ascd.org/ASCD/pdf/journals/ed_lead/el_198510_ennis.pdf [17 Desember 2016]

Fisher, A. (2009). Berpikir Kritis : Sebuah Pengantar. Terjemahan Benyamin Hadinata. Critical Thinking : An Introduction. Cambridge : Cambridge University Press

Istianah, E. (2013). "Meningkatkan Kemampuan Berpikir Kritis dan Kreatif Matematik dengan Pendekatan Model Eliciting Activities (MEAs) pada Siswa SMA". Jurnal Ilmiah Program Studi Matematika STKIP Siliwangi Bandung, Vol 2(1), 43-54. [Online]. Tersedia di : http://e-journal.stkipsiliwangi.ac.id/index.php/infinity/article/ view/23/22 [5 Desember 2016]

Johnson, B. (2007). Contextual Teaching and Learning : Menjadikan Kegiatan Belajar Mengajar Mengasyikan dan Bermakna. Terjemahan Ibnu Setiawan. Contextual Teaching and Learning : What it is and Why it's Here to Stay. California : Corwin Press

Kemendikbud. (2014). Materi Pelatihan Implementasi Kurikulum 2013 Mata Pelajaran Matematika SMP/MTs. Jakarta : Badan Pengembangan Sumber Daya Manusia Pendidikan dan Kebudayaan dan Penjaminan Mutu Pendidikan

Kramarski, B. et al. (2002). "The Effect of Metacognitive Instruction on Solving Mathematical Authentics Tasks". Educational Studies in Mathematics, Vol 49, 225-250. [Online]. Tersedia di https://www.researchgate.net/profile/Bracha_Kramarski/publication/225738323_The_effects_ of_metacognitive_instruction_on_solving_mathematical_authentic_tasks/links/5523da960cf2 c815e0734148/The-effects-of-metacognitive-instruction-on-solving-mathematical-authentictasks.pdf [18 November 2016] 


\section{Tety Septiani}

Upaya Meningkatan Kemampuan Berpikir Kritis Siswa Menggunakan Model Pembelajaran Improve

Mevarech, Z dan Bracha Kramarski. (1997). "IMPROVE : A Multidimensional Method For Teaching Mathematics in Heterogeneous Classrooms". American Education Research Journal, Vol 34(2), 365-394. [Online]. Tersedia di : http://journals.sagepub.com/ doi/pdf/10.3102/00028312034002365 [18 November 2016]

NCTM. (1989). Curriculum and Evaluation Standards for School Mathematics. Reston VA : The Council

Polya, G. (1985). How To Solve It : A New Aspect of Mathematical Method. New Jersey : Princeton University Press

Sudijono, A. (2008). Pengantar Evaluasi Pendidikan. Jakarta : PT Raja Grafindo Persada Sudjana, N. (2010). Penilaian Hasil Proses Belajar Mengajar. Bandung : Remaja Rosdakarya Suryosubroto. (2009). Proses Belajar Mengajar di Sekolah. Jakarta : Rineka Cipta 